info@masteb.com

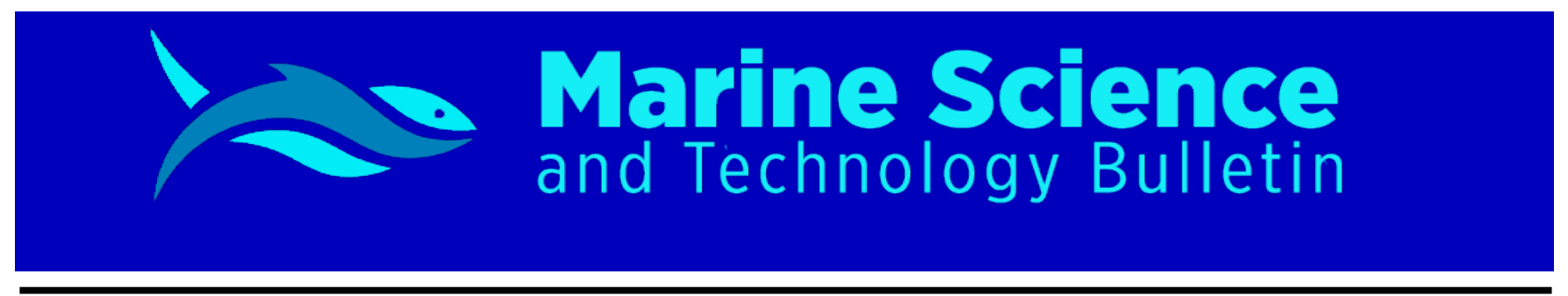

RESEARCH ARTICLE

\title{
Trend analysis of mean monthly, seasonally and annual streamflow of Daday Stream in Kastamonu, Turkey.
}

\author{
Semih Kale ${ }^{1^{*}}$ (D) Adem Yavuz Sönmez ${ }^{2}$ \\ ${ }^{1}$ Department of Fishing and Fish Processing Technology, Faculty of Marine Sciences and Technology, Çanakkale Onsekiz Mart University, Çanakkale, \\ Turkey \\ ${ }^{2}$ Department of Basic Sciences, Faculty of Fisheries, Kastamonu University, Kastamonu, Turkey
}

\section{ARTICLE INFO}

Article History:

Received: 24.04 .2018

Received in revised form: 13.09.2018

Accepted: 05.10.2018

Available online: 01.11.2018

Keywords:
Climate change
Change-point analysis
Daday
Streamflow
Trend analysis

\begin{abstract}
A B S T R A C T
Water is one of the most important natural resources and assessment of the trends in water has a great importance to estimate the future of water resources. The main purpose of this study is to present a trend analysis of the streamflow of Daday Stream in Kastamonu, Turkey by monthly, seasonally and annual analyses. Monthly streamflow data were obtained from streamflow gauging station on the stream between 1988 and 2007. Trends of monthly, seasonal and annual runoff of Daday Stream were analysed by Trend analysis, non-parametric Mann-Kendall and Spearman tests. The results showed that mean annual streamflow of Daday Stream had a significant tendency to decrease for this period $(\mathrm{p}<0.01)$. The results of seasonal trend analysis results demonstrated that statistically significant decreasing trends were found for all seasons. Trend analyses for monthly mean streamflow displayed that there were also statistically significant decreasing trends for all month excluding February, March, April, and June. In conclusion, decreasing trends in the streamflow of Daday Stream have been predicted for this period and for the future. The fluctuation in water resources could be affected by some reasons such as decreasing rainfall, rising temperature depending upon climate change.
\end{abstract}

Please cite this paper as follows:

Kale, S., Sönmez, A.Y. (2018). Trend analysis of mean monthly, seasonally and annual streamflow of Daday Stream in Kastamonu, Turkey. Marine

Science and Technology Bulletin, 7(2): 60-67.

\section{Introduction}

Water is one of the most important natural resources and many studies focused on water to investigate the temporal variations or characteristics of water with different purposes around the world. The Intergovernmental Panel on Climate Change (IPCC, 2007) noted that water resources are under pressure and stress by some reasons such as growing population, greenhouse gases, temporal variations, climate change, and other reasons for half a century. Interactions between climatic parameters and topography, vegetation, and soil affecting evaporation, precipitation, and infiltration define the streamflow (Dingman, 2002; Brutsaert, 2005). These processes and the regime of the streamflow are commonly estimated to be affected by the climate change (Zhou et al., 2014; Christensen et al., 2004; Stewart et al., 2004).

\footnotetext{
* Corresponding author

E-mail address: semihkale@comu.edu.tr (S. Kale)
} 
The temporal patterns of streamflow is sensitive to the climate change. The impacts of the climate change on the hydrologic processes in rivers are widely accepted by many authors. A few scientists have investigated the projected effects of climate change on streamflows at a regional scale (Christensen et al., 2004; Stewart et al., 2004; Reidy and Liermann et al., 2012). Current trends of the streamflows should be determined and monitored, and future trends should also be predicted to understand the possible effects of the climate change. Assessment of the trends in water parameters has a great importance to estimate the future of water resources. Therefore, investigations on the trend of water resources and rivers provide valuable contributions to the knowledge for the water resources management and decision-making process.

Several authors have analysed trends in climatic and hydrologic parameters (Kadığlu, 1997; Büyükyıldız and Berktay, 2004; Şensoy et al., 2005; Cigizoglu et al., 2005; Yıldırım et al., 2013; Saplığlu et al., 2014; Sütgibi, 2015; Yenigün and Ülgen, 2016; Ay and Özyıldırım, 2017; Ercan and Yüce, 2017; Tosunoğlu, 2017; Tosunoglu and Kisi, 2017). Also numerous studies determined trends in water parameters by using different methods (Sen, 1968; Hirsch et al., 1982; Helsel and Hirsch, 2002; Şen, 2012). In Turkey, trend analysis for water parameters were firstly carried out by İçă̆a (1994). Afterwards, many authors conducted studies to estimate the trends in water parameter (İçağa and Harmancıoğlu, 1995; Kalayci and Kahya, 1998; Albek, 2002; Kişi and Ay, 2014; Doğan Demir et al., 2016; Ejder et al., 2016a, 2016b; Kale et al., 2016a, 2016b; Kişi et al., 2018; Kale et al., 2018). Unfortunately, there is no study on determining and monitoring trends of the streamflow of Daday Stream. Therefore, the main purpose of this study is to present a trend analysis of the streamflow of Daday Stream in Kastamonu, Turkey.

\section{Material and Methods}

\section{Study Area}

Daday Stream arises from Çamlıbel village and runs through the villages of Akılçalman, Örencik, Akpınar, Bolatlar, Tüfekçi, Sarıçam, Yazıcameydan, İnciğez, Kızılörencik, Eymir, Hacımuharrem, Talipler, Çiğil, Dokuzkat, Göcen, Subaşı, Numanlar, Gölköy, Emirler, Sarı̈mer, Koruköy, Hocaköy, Mollaköy, Kurtgömeç, Hasköy, Kurusaray, Emirli, Hatipköy, Eşenköy and the city centre of Daday district and Kastamonu province (Figure 1). It merges with Karasu Stream in Bükköy as tributaries of Gökırmak Stream. The climate of the region is typical continental climate with snowy winters, warm summers in drier conditions, and spring and autumn seasons that are often sharp cold and frost which is unfavourable for agriculture and production of vegetables and fruits. Daday Stream rises from $1217 \mathrm{~km}$ and its length is calculated $72.3 \mathrm{~km}$.

Streamflow data were obtained from streamflow gauging station at Hasköy (D15A225) of the General Directorate of State Hydraulic Works (DSI). Analyses were carried out for each of mean monthly, seasonal, and annual data.

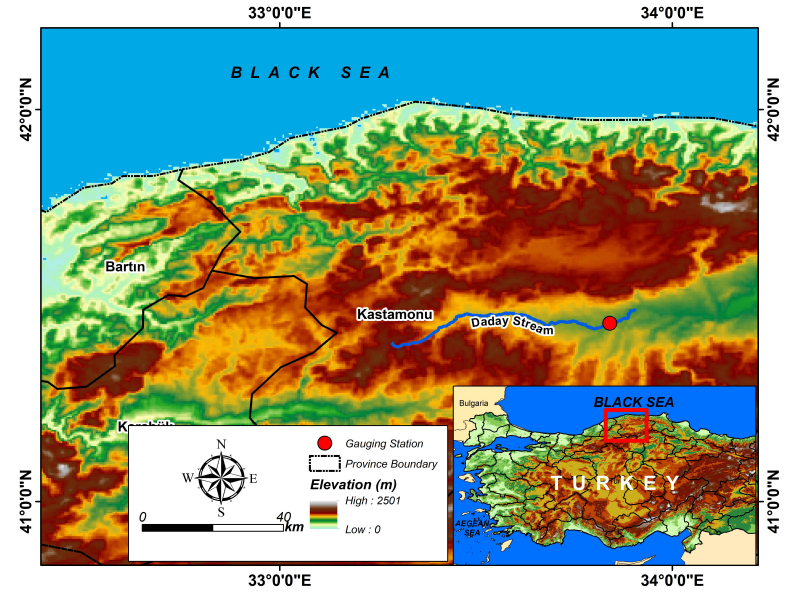

Figure 1. The location of Daday Stream.

\section{Change Point Analysis}

Pettitt's change-point analysis (Pettitt, 1979) was used to detect the change time of the streamflow data. This non-parametric test was modified from the Mann-Whitney statistic and detects significant changes in the averages of time series. Pettitt's change-point analysis was performed in R statistical software (R Core Team, 2017). The formulae as follow:

$$
\begin{gathered}
U_{t, T}=\sum_{i=1}^{t} \sum_{j=t+1}^{T} \operatorname{sgn}\left(x_{i}-x_{j}\right) \text { for } t=2, \ldots \ldots, T \\
K_{T}=\max \left|U_{t, T}\right|,
\end{gathered}
$$

The null hypothesis of the change-point test is the absence of change point. The statistic of null hypothesis is $K_{T}$. $U_{t, T}$, confirms whether two examples $\left(x_{1}, \ldots \ldots, x_{t}\right.$ and $\left.x_{t}+1, \ldots \ldots, x_{T}\right)$ are in the same population or not. Associated probability $(p)$ is used for computing the significance.

\section{Trend Analysis}

Trend analysis is commonly used method to determine the tendency in a hydrological time series. Box-Jenkins technique (Box and Jenkins, 1976) and the auto regressive integrated moving average model were applied to understand the trend of streamflow. In ARIMA model $(p, d, q), p$ shows the number of auto regressive terms, $q$ shows the number of moving average terms and $d$ shows the differencing order. The ARIMA model used in the study as follow:

$$
X_{t}=c+\Phi_{1} X_{t-1}+\cdots+\Phi_{p} X_{t-p}+\theta_{1} e_{t-1}+\theta_{q} e_{t-q}+e_{t}
$$

In this equation, $X_{t}$ is the variable will be described in $t$ time, $c$ is the constant, $\Phi$ is coefficient of per $p$ parameter, $\theta$ is the coefficient of per $q$ parameter, and $e_{t}$ is the error in $t$ time.

\section{Mann-Kendall Test}

Mann-Kendall test (Kendall, 1955; Mann, 1945) is a widely used test to explore the trends in a time series. Non-parametric MannKendall test and Spearman's rho test offer more trustworthy results than parametric tests. One advantage of this non-parametric test is that 
the data do not require to track any specific distribution. The formulae for this test are as follows:

$$
S=\sum_{i=1}^{n-1} \sum_{k=i+1}^{n} \operatorname{sgn}\left(x_{k}-x_{i}\right)
$$

In this equation, the time series $x_{i}$ is from $i=1,2, \ldots, n-1$, and $x_{k}$ from $k=i+1, \ldots, n$.

$$
\operatorname{sgn}(\theta)=\left\{\begin{aligned}
+1, & \theta>0 \\
0, & \theta=0 \\
-1, & \theta=0
\end{aligned}\right.
$$

Normalized test statistic is computed by the follow equation:

$$
Z_{c}= \begin{cases}\frac{S-1}{\sqrt{\operatorname{var}(S)},}, & S>0 \\ \frac{S+1}{\sqrt{\operatorname{var}(S)},}, & S=0\end{cases}
$$

$Z_{c}$ is the test statistic and when $\left|Z_{c}\right|>Z_{1-\alpha / 2}$, in which $Z_{1-\alpha / 2}$ are the standard normal variables and $\alpha$ is the significance level for the test, $H_{0}$ will be rejected. The magnitude of the trend is given as follow:

$$
\beta=\operatorname{Median}\left(\frac{x_{i}-x_{j}}{i-j}\right), \forall_{j}<i, \text { where } 1<j<i<n .
$$

A negative value of $\beta$ shows a decreasing trend, while a positive value of $\beta$ shows an increasing trend.

\section{Results}

The descriptive statistics of the runoff data including mean with standard deviation, coefficient of variation (CV), coefficient of skewness, maximum and minimum values and range are listed in Table 1.

The results of change point analysis indicated that the change point for mean annual runoff was 1993. As a result of the trend analysis, a decreasing trend was found for mean annual runoff (Figure 2).

For mean seasonal runoff, change points were detected 1993, 1993, 1999, and 2002 for spring, summer, autumn, and winter, respectively. The results of trend analyses showed that runoff has decreasing trends for all seasons (Figure 3).

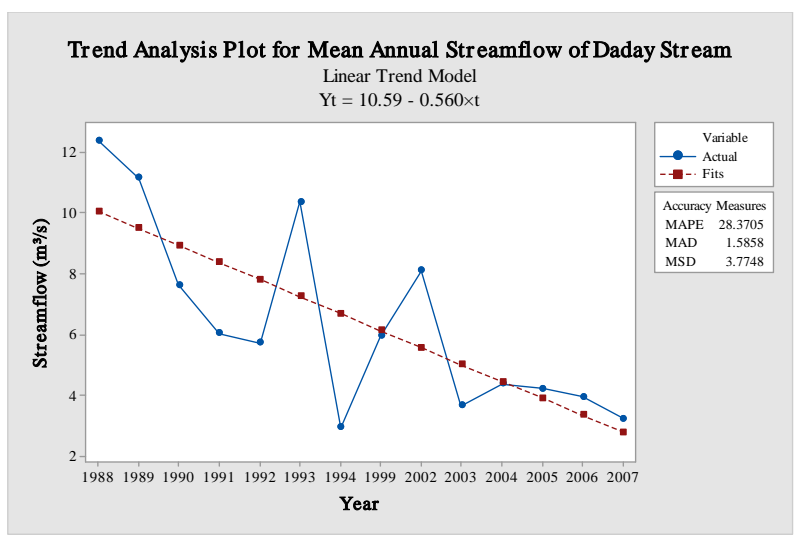

Figure 2. Trend analysis result of mean annual streamflow.

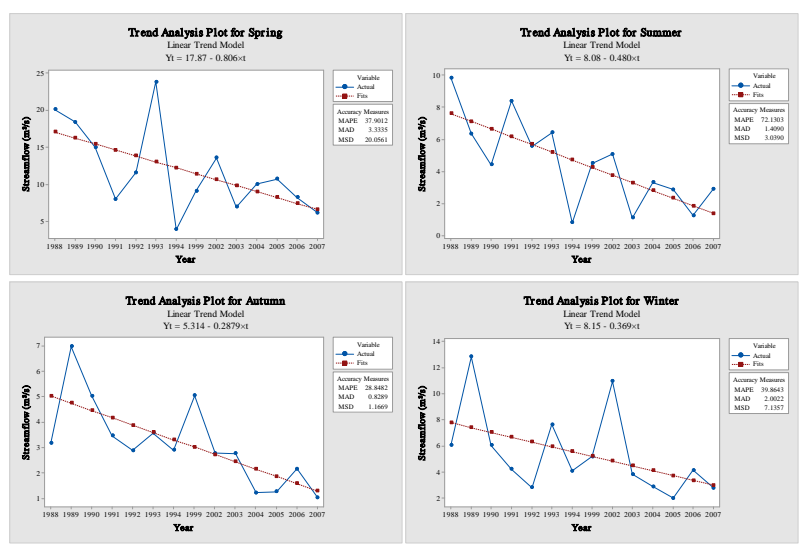

Figure 3. Trend analysis results of mean seasonal streamflow.

Change point analysis results detected the change point years for mean monthly runoff as 1999, 2002, 1993, 2004, 1993, 1993, 2002, 2002, 2002, 1999, 1999, and 2002 for the months from January to December, respectively. Trend analysis results showed that mean monthly runoff have decreasing trends for all months (Figure 4).

Results of Mann-Kendall trend tests pointed out that there is a statistically significant decreasing trend in the series of mean annual runoff $(\mathrm{p}<0.01)$. Also statistically significant decreasing trends were found for mean seasonal runoff for all seasons. Moreover, there were statistically significant decreasing trends for mean monthly runoff for all months excluding February, March, April, and June (Table 2).

Table 1. Basic statistics of streamflow data.

\begin{tabular}{lrrrrrrr}
\hline Mean Streamflow & Average & $\begin{array}{c}\text { Standard } \\
\text { deviation }\end{array}$ & $\begin{array}{c}\text { Coefficient of } \\
\text { variation }\end{array}$ & $\begin{array}{c}\text { Coefficient of } \\
\text { skewness }\end{array}$ & $\begin{array}{c}\text { Maximum } \\
\text { value }\end{array}$ & $\begin{array}{c}\text { Minimum } \\
\text { value }\end{array}$ & Range \\
\hline Annual & 6.40 & 3.09 & 0.48 & 0.56 & 12.38 & 2.91 & 9.47 \\
Spring & 11.83 & 5.74 & 0.49 & 0.77 & 23.87 & 3.91 & 19.96 \\
Summer & 4.48 & 2.70 & 0.60 & 0.04 & 9.84 & 0.78 & 9.06 \\
Autumn & 3.16 & 1.65 & 0.52 & 0.49 & 6.97 & 1.03 & 5.94 \\
Winter & 5.38 & 3.17 & 0.59 & 1.15 & 12.83 & 1.99 & 10.84 \\
\hline
\end{tabular}




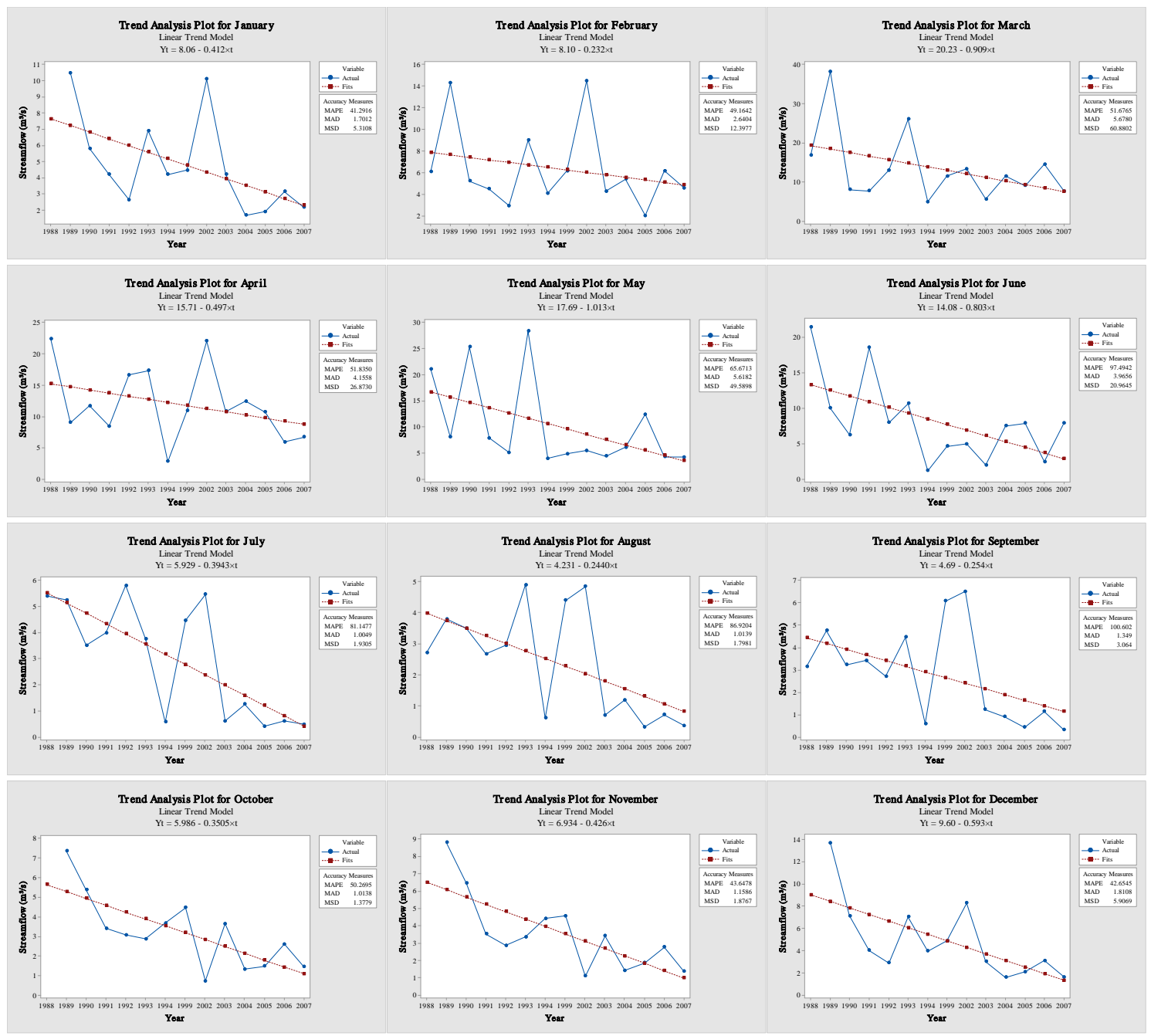

Figure 4. Trend analysis results of mean monthly streamflow.

Table 2. Non-parametric tests values and trend status.

\begin{tabular}{|c|c|c|c|c|c|c|c|}
\hline Period & Streamflow & Kendall's tau & $p$ & Trend & Spearman's rho & $p$ & Trend \\
\hline & Annual & -0.604 & 0.003 & $\nabla$ & -0.741 & 0.002 & $\nabla$ \\
\hline \multirow{4}{*}{ 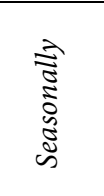 } & Spring & -0.429 & 0.033 & $\nabla$ & -0.578 & 0.030 & $\nabla$ \\
\hline & Summer & -0.516 & 0.010 & $\boldsymbol{\nabla}$ & -0.710 & 0.004 & $\boldsymbol{\nabla}$ \\
\hline & Autumn & -0.648 & 0.001 & $\nabla$ & -0.815 & 0.000 & $\nabla$ \\
\hline & Winter & -0.473 & 0.019 & $\boldsymbol{\nabla}$ & -0.631 & 0.016 & $\nabla$ \\
\hline \multirow{12}{*}{ 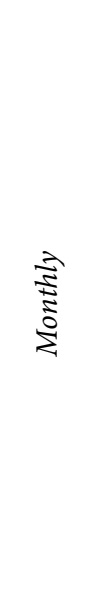 } & January & -0.452 & 0.032 & $\nabla$ & -0.644 & 0.018 & $\nabla$ \\
\hline & February & -0.143 & 0.477 & & -0.178 & 0.543 & \\
\hline & March & -0.221 & 0.273 & & -0.339 & 0.236 & \\
\hline & April & -0.275 & 0.171 & & -0.376 & 0.185 & \\
\hline & May & -0.407 & 0.043 & $\boldsymbol{\nabla}$ & -0.569 & 0.034 & $\nabla$ \\
\hline & June & -0.319 & 0.112 & & -0.516 & 0.059 & \\
\hline & July & -0.486 & 0.016 & $\nabla$ & -0.664 & 0.010 & $\nabla$ \\
\hline & August & -0.363 & 0.071 & $\nabla$ & -0.552 & 0.041 & $\nabla$ \\
\hline & September & -0.385 & 0.055 & $\nabla$ & -0.569 & 0.034 & $\nabla$ \\
\hline & October & -0.513 & 0.015 & $\nabla$ & -0.709 & 0.007 & $\nabla$ \\
\hline & November & -0.538 & 0.010 & $\nabla$ & -0.753 & 0.003 & $\boldsymbol{\nabla}$ \\
\hline & December & -0.513 & 0.015 & $\nabla$ & -0.687 & 0.010 & $\boldsymbol{\nabla}$ \\
\hline
\end{tabular}

Note: $\mathbf{\nabla}$ indicates statistically significant trends. 


\section{Discussion}

Water resources are limited in the worldwide and several countries will face serious water shortages and/or scarcities on limited resources due to the impacts of global warming and climate change (Hisar et al., 2015). Therefore, investigations on the trend of water resources and rivers provide valuable contributions to the knowledge for the water resources management and decision-making process.

There are many studies about trend analysis on climatic parameters such as temperature (Türkeş et al., 1996; Han et al., 2012; Limjirakan and Limsakul, 2012; Doğan Demir and Demir, 2016; Demir et al., 2008; Duman and Kara, 2017; Kale, 2017a), evaporation (Tebakari et al., 2005; Jaswal et al., 2008; Kale, 2017b; Bacanlı and Tanrıkulu, 2017), and precipitation (Partal and Kahya, 2006; Aslantaş Bostan and Akyürek, 2007, 2010; Kızılelma et al., 2015; Doğan Demir and Demir, 2017; Yavuz and Erdoğan 2012; Bacanlı and Tanrıkulu, 2016; Bacanli, 2017; Taylan and Aydın, 2018). Trend analyses were also carried out to determine the trends in the streamflow. Numerous authors have reported decreasing trends in the streamflow of rivers. Durdu (2010) reported decreasing trend in Büyük Menderes River basin. Zhou et al. (2015) informed that there was a decrease in Huangfuchuan River streamflow. Herawati et al. (2015) found decreasing trend in streamflow of rivers in Indonesia. Pumo et al. (2016) stated that streamflow presented a significantly decreasing trend in non-perennial small rivers in Italy. Ozkul (2009) and Ozkul et al. (2008) informed about decreasing trends in the streamflow of Gediz and Büyük Menderes rivers. Türkeş and Acar Deniz (2011) described decreasing trend in the streamflow of the southern Marmara rivers. Bahadir (2011), Kahya and Kalaycı (2004), Koçman and Sütgibi (2012) reported that streamflow of rivers tended to decrease. Ejder et al. (2016a) described a decreasing trend in Sarıçay streamflow while Ejder et al. (2016b) documented a decreasing trend in the streamflow of Kocabaş Stream. Kale et al. (2016a) and Kale et al. (2016b) informed that decreasing trends were found in the streamflow of Karamenderes and Bakırçay rivers, respectively. Kişi et al. (2018) described decreasing and increasing trends in monthly streamflow of three different basins in Turkey. Kale et al. (2018) recently documented decreasing trends in rivers in western Turkey. Kale and Sönmez (2018) also reported decreasing trends in the streamflow of Akkaya Stream in Turkey and highlighted that decreasing trends were found statistically significant for mean annual, seasonal and monthly streamflow. Authors claimed that decreasing trend in the streamflow of Akkaya Stream could be attributed to decrease in rainfall and snowmelt, tremendously increase in temperature of air and water and other causes resulted from the climate change.

In this paper statistically significant decreasing trends were found for mean annual, seasonal, and monthly (excluding February, March, April, and June) streamflow. The findings of the present study are related to other reported trend analyses researches on hydrologic parameters. These decreasing trends could be related to the climate change especially rainfall and temperature. Changes in the climate such as rising temperature and decreasing rainfall may affect the streamflow and availability of water resources. On the other hand,
Bates et al. (2008) stated that trends in streamflow were not always related to the variations in the precipitation. Some authors noticed that agricultural activities (Durdu, 2010; Dügel and Kazanci, 2004; Kaçan et al., 2007; Yercan et al., 2004), hydraulic structures (Ozkul et al., 2008) and human activities (Gao et al., 2011; Jackson et al., 2011; Zhou et al., 2015) had effects on the river streamflow along with the effects of the climate change.

\section{Conclusion}

Trends of monthly, seasonal and annual streamflow of Daday Stream were analysed. Statistically significant decreasing trends were found for mean annual, seasonal, and monthly streamflow excluding the months of February, March, April, and June. This study is the first study on determining and monitoring trends of the streamflow of Daday Stream. So, this paper provides significant information about past, current and future trends of the streamflow of Daday Stream. The amount of streamflow and water resources could be affected by some reasons such as decreasing rainfall, rising temperature depending upon climate change. In future period, it is predicted that decreasing trend will continue for Daday Stream. Therefore, available water resources should be effectively and efficiently managed. Sustainable use of water resources should be ensured to maintain the sustainability of natural resources.

\section{Conflict of Interest}

The authors declare that there is no conflict of interest.

\section{Acknowledgements}

The authors would like to thank The General Directorate of State Hydraulic Works (DSİ) for supplying streamflow data.

\section{References}

Albek, E. (2002). Statistical analysis of water quality trends: an application to the Porsuk Stream. Anadolu University Journal of Science and Technology, 3(2): 281-292.

Aslantaş Bostan, P. \& Akyürek, Z. (2010). Spatio-Temporal Analysis of Precipitation and Temperature Distribution over Turkey. In: International Conference on Theory, Data Handling and Modelling in GeoSpatial Information Science. Hong Kong, Hong Kong: The International Archives of the Photogrammetry, Remote Sensing and Spatial Information Sciences, 38(Part II): 92-97.

Aslantaş Bostan, P. \& Akyürek, Z. (2007). Exploring the mean annual precipitation and temperature values over Turkey by using environmental variables. In: ISPRS Joint Workshop "Visualization and Exploration of Geospatial Data". Stuttgart, Germany: The International Archives of the Photogrammetry, Remote Sensing and Spatial Information Sciences, 38(4/W45): 23. 
Ay, M. \& Özyıldırım, S. (2017). Trend Analysis of Monthly Total Rainfall and Monthly Mean Air Temperature Variables of Yozgat in Turkey. Çukurova University Journal of the Faculty of Engineering and Architecture, 32(2): 65-75.

Bacanl, Ü.G. (2017). Trend analysis of precipitation and drought in the Aegean region, Turkey. Meteorological Applications, 24: 239-249.

Bacanlı, Ü.G. \& Tanrıkulu, A. (2017). Trends Analysis of Evaporation Datas in Aegean Region. Afyon Kocatepe University Journal of Science and Engineering, 17(035403): 980-987.

Bacanl, Ü.G. \& Tanrikulu, A. (2016). Trends in Yearly Precipitation and Temperature on the Aegean Region, Turkey. Ovidius University Annals Series: Civil Engineering, 18: 203-210.

Bahadir, M. (2011). A Statistical Analysis of the Flow Changes of Kizılırmak River. Turkish Studies - International Periodical for the Languages, Literature and History of Turkish or Turkic, 6: 1339-1356.

Bates, B.C., Kundzewicz, Z.W., Wu, S. \& Palutikof, J.P. (2008). Climate Change and Water. 6th Technical Paper of the Intergovernmental Panel on Climate Change. IPCC Secretariat, Geneva, 210p.

Box, G.E.P. \& Jenkins, G. (1976). Time Series Analysis: Forecasting and Control. Holden Day, San Francisco. 575p.

Büyükyıldız, M. \& Berktay, A. (2004). Parametrik Olmayan Testler Kullanilarak Sakarya Havzasi Yağişlarinin Trend Analizi. Journal of Faculty of Engineering and Architechture of Selcuk University, 19(2): 23-38.

Cigizoglu, H. K., Bayazit, M. \& Onoz, B. (2005). Trends in the maximum, mean and low flows of Turkish rivers. Journal of Hydrometeorology, 6(3): 280-290.

Demir, İ., Kılıç, G., Coşkun, M. \& Sümer, U.M. (2008). Türkiye'de Maksimum, Minimum ve Ortalama Hava Sıcaklıkları ile Yağış Dizilerinde Gözlenen Değişiklikler ve Eğilimler. TMмОВ İklim Değişimi Sempozyumu Bildiriler Kitabı, Ankara, Turkey. pp. 69-84.

Doğan Demir, A. \& Demir, Y. (2016). Mean, Minimum and Maximum Temperature Trends in Bingöl. Middle East Journal of Science, 2(2): 101-109.

Doğan Demir, A., Demir, Y., Şahin, Ü. \& Meral, R. (2017). Trend Analyses of Temperature and Precipitation and Effect on Agricultural in Bingol Province. Türk Tarım ve Doğa Bilimleri Dergisi, 4(3): 284-291.

Doğan Demir, A., Şahin, Ü. \& Demir, Y. (2016). Trend Analysis and Agricultural Perspective Availability of Water Quality Parameters at Murat River. Yuzuncu Yll University Journal of Agricultural Sciences, 26(3): 414-420.

Duman, E. \& Kara, F. (2017). A Study on Trends and Variability in Monthly Temperatures in Antalya Province between the Years 1960 and 2015. Journal of Scientific Research \& Reports, 14(2): 1-16.
Durdu, Ö.F. (2010). Effects of climate change on water resources of the Büyük Menderes river basin, western Turkey. Turkish Journal of Agriculture and Forestry, 34: 319-332.

Dügel, M. \& Kazanci, N. (2004). Assessment of water quality of the Büyük Menderes River (Turkey) by using ordination and classification of macroinvertebrates and environmental variables. Journal of Freshwater Ecology, 19: 605-612.

Ercan, B. \& Yüce, M.İ. (2017). Trend Analysis of HydroMeteorological Variables of Kızılırmak Basin. Nevşehir Bilim ve Teknoloji Dergisi, 6(ICOCEE 2017 Özel Sayı): 333-340.

Ejder, T., Kale, S., Acar, S., Hisar, O. \& Mutlu, F. (2016a). Effects of Climate Change on Annual Streamflow of Kocabaş Stream (Çanakkale, Turkey). Journal of Scientific Research and Reports, 11(4): 1-11.

Ejder, T., Kale, S., Acar, S., Hisar, O. \& Mutlu, F. (2016b). Restricted effects of climate change on annual streamflow of Sarıçay stream (Çanakkale, Turkey). Marine Science and Technology Bulletin, 5(1): 7-11.

Gao, P., Mu, X.M., Wang, F. \& Li, R. (2011). Changes in streamflow and sediment discharge and the response to human activities in the middle reaches of the Yellow River. Hydrology and Earth System Sciences, 15: 1-10.

Han, S., Xu, D. \& Wang, S. (2012). Decreasing potential evaporation trends in China from 1956 to 2005: Accelerated in regions with significant agricultural influence? Agricultural and Forest Meteorology, 154-155: 44-56.

Helsel, D.R. \& Hirsch, R.M. (2002). Statistical Methods in Water Resources Techniques of Water Resources Investigations, Book 4, Chapter A3. U.S. Geological Survey. 522p.

Herawati, H., Suripin \& Suharyanto. (2015). Impact of Climate Change on Streamflow in the Tropical Lowland of Kapuas River, West Borneo, Indonesia. Procedia Engineering, 125: 185-192.

Hirsch, R.M., Slack, J.R. \& Smith, R.A. (1982). Techniques of trend analysis for monthly water quality analysis. Water Resources Research, 18(1): 107-121

Hisar, O., Kale, S. \& Özen, Ö. (2015). Sustainability of Effective Use of Water Sources in Turkey. In: Leal Filho, W., Sümer, V. (Eds.), Sustainable Water Use and Management: Examples of New Approaches and Perspectives. Springer International Publishing, Switzerland, pp. 205-227.

İçağa, Y. (1994). Analysis of Trends in Water Quality Using Nonparametric Methods. MSc Thesis, Dokuz Eylül University, İzmir, Turkey. 143p.

İçağa, Y. \& Harmancıoğlu, N. (1995). Determination of Water Quality Trends in the Yeşilırmak River Basin. Proceedings of the 13. Technical Congress of Civil Engineering, Ankara, Turkey. pp. 481-498.

IPCC, (2007). Climate Change 2007: Impacts, Adaptation and Vulnerability: Working Group II Contribution to the Fourth Assessment Report of the Intergovernmental Panel on Climate Change. Cambridge University Press, Cambridge, UK, 976p. 
Jackson, C.R., Meister, R. \& Prudhomme, C. (2011). Modelling the effects of climate change and its uncertainty on UK Chalk groundwater resources from an ensemble of global climate model projections. Journal of Hydrology, 399: 12-28.

Jaswal, A.K., Prakasa Rao, G.S. \& De, U.S. (2008). Spatial and temporal characteristics of evaporation trends over India 1971-2000. MAUSAM, 59(2): 149-158.

Kaçan, E., Ülkü, G. \& Turan, F. (2007). Total pollution load discharged to creeks and River Buyuk Menderes near Denizli City. Proceedings of the International Congress on River Basin Management. Antalya, Turkey, pp. 54-63.

Kadıoğlu, M. (1997). Trends in Surface Air Temperature Data over Turkey. International Journal of Climatology, 15: 511-520.

Kahya, E. \& Kalayc1, S. (2004). Trend analysis of streamflow in Turkey. Journal of Hydrology, 289: 128-144.

Kalayci, S. \& Kahya, E. (1998). Detection of Water Quality Trends in The Rivers of the Susurluk Basin. Turkish Journal of Engineering and Environmental Science, 22: 503-514.

Kale, S., Ejder, T., Hisar, O. \& Mutlu, F. (2016a). Climate Change Impacts On Streamflow of Karamenderes River (Çanakkale, Turkey). Marine Science and Technology Bulletin, 5(2): 1-6.

Kale, S., Ejder, T., Hisar, O. \& Mutlu, F. (2016b). Effect of Climate Change on Annual Streamflow of Bakırçay River. Adıyaman University Journal of Science, 6(2): 156-176.

Kale, S. (2017a). Climatic Trends in the Temperature of Çanakkale City, Turkey. Natural and Engineering Sciences, 2(3): 14-27.

Kale, S. (2017b). Analysis of Climatic Trends in Evaporation for Çanakkale (Turkey). Middle East Journal of Science, 3(2): 6982.

Kale, S., Hisar, O., Sönmez, A.Y., Mutlu, F. \& Filho, W.L. (2018). An Assessment of the Effects of Climate Change on Annual Streamflow in Rivers in Western Turkey. International Journal of Global Warming, 15(2): 190-211.

Kale, S. \& Sönmez, A.Y. (2018). Trend Analysis of Streamflow of Akkaya Stream (Turkey). Proceedings of the 1st International Conference on Food, Agriculture and Animal Sciences, Antalya, Turkey. pp. 33-45.

Kendall, M.G. (1955). Rank Correlation Methods. 2nd ed. Hafner Publishing Co., New York. 196p.

Kızılelma, Y., Çelik, M.A. \& Karabulut, M. (2015). Trend analyses of temperature and precipitations in Central Anatolia. Türk Coğrafya Dergisi, 64: 1-10.

Kişi, Ö., Guimarães Santos, C.A., Marques da Silva, R. \& ZounematKermani, M. (2018). Trend analysis of monthly streamflows using Şen's innovative trend method. Geofizika, 35(1): 5368.

Koçman, A. \& Sütgibi, S. (2012). Hydrograpic/hydrologic characteristics of Gediz river basin in the context of the environmental components - problems and suggestions. Eastern Geographical Review, 28: 155-174.

Limjirakan, S. \& Limsakul, A. (2012). Observed Trends in Surface Air Temperatures and Their Extremes in Thailand from 1970 to
2009. Journal of the Meteorological Society of Japan, 90(5): 647-662.

Ozkul, S. (2009). Assessment of climate change effects in Aegean river basins: the case of Gediz and Buyuk Menderes Basins. Climatic Change, 97: 253-283.

Ozkul, S., Fistikoglu, O. \& Harmancioglu, N. (2008). Evaluation of climate change effects on water resources in the case of Gediz and Büyük Menderes river basins. TMMOB 2. Su Politikaları Kongresi Bildiriler Kitabı, Ankara, TURKEY, pp. 309-322.

Partal, T. \& Kahya, E. (2006). Trend analysis in Turkish precipitation data. Hydrological Processes, 20(9): 2011-2026.

Pettitt, A.N. (1979). A Non-Parametric Approach to the Change-Point Problem. Journal of the Royal Statistical Society. Series C (Applied Statistics), 28: 126-135.

Pumo, D., Caracciolo, D., Viola, F. \& Noto, L.V. (2016). Climate change effects on the hydrological regime of small nonperennial river basins. Science of the Total Environment, 542 (Part A): 76-92.

R Core Team. (2017). R: A Language and Environment for Statistical Computing. R Foundation for Statistical Computing, Vienna, Austria [online] https://www.R-project.org/version (07/2017)

Saplığlu, K., Kilit, M. \& Yavuz, B.K. (2014). Trend Analysis of Streams in the Western Mediterranean Basin of Turkey. Fresenius Environmental Bulletin, 23(1):1-12.

Sütgibi, S. (2015). Variations and Trends in Temperature, Precipitation and Stream-flow Series in the Büyük Menderes River Basin. Marmara Coğrafya Dergisi, 31: 398-414

Sen, P.K. (1968). Estimates of the regression coefficient based on Kendall's tau. Journal of the American Statistical Association, 63(324): 1379-1389.

Şen, Z. (2012). Innovative trend analysis methodology. Journal of Hydrologic Engineering, 17(9): 1042-1046.

Şensoy, S., Demircan, M. \& Alan, İ. (2005). 1971 - 2004 Yılları Arası Türkiye İklim İndisleri Trendleri. Devlet Meteoroloji İşleri Genel Müdürlüğü, Ankara, Turkey.

Taylan, D. \& Aydın, T. (2018). The Trend Analysis of Lakes Region Precipitation Data in Turkey. Cumhuriyet Science Journal, 39(1): 258-273.

Tebakari, T., Yoshitani, J. \& Suvanpimol, C. (2005). Time-Space Trend Analysis in Pan Evaporation over Kingdom of Thailand. Journal of Hydrologic Engineering, 10(3): 205-215.

Tosunoglu, F. \& Kisi, O. (2017). Trend Analysis of Maximum Hydrologic Drought Variables Using Mann-Kendall and Şen's Innovative Trend Method. River Research and Applications, 33: 597-610.

Tosunoğlu, F. (2017). Trend Analysis of Daily Maximum Rainfall Series in Çoruh Basin, Turkey. Iğdır University Journal of the Institute of Science and Technology, 7(1): 195-205.

Türkeş, M. \& Acar Deniz, Z. (2011). Climatology of South Marmara Division (North West Anatolia) and observed variations and 
trends. International Journal of Human Sciences, 8: 15791600.

Türkeş, M., Sümer, U., Kılıç, G. (1996). Observed Changes in Maximum and Minimum Temperatures in Turkey. International Journal of Climatology, 16(4): 463-477.

Yavuz, H. \& Erdoğan, S. (2012). Spatial Analysis of Monthly and Annual Precipitation Trends in Turkey. Water Resources Management, 26(3): 609-621.

Yenigün, K. \& Ülgen, M.U. (2016). Trend analysis of maximum flows under climate change evaluation and its impact on spillway. Disaster Science and Engineering, 2(1): 25-28.
Yercan, M., Dorsan, F. \& Ul, M. (2004). Comparative analysis of performance criteria in irrigation schemes: a case study of Gediz river basin in Turkey. Agricultural Water Management, 66: 259-266.

Yıldırım, U., Yılmaz, İ.Ö. \& Akınoğlu, B.G. (2013). Trend analysis of 41 years of sunshine duration data for Turkey. Turkish Journal of Engineering \& Environmental Sciences, 37: 286305.

Zhou, Y., Shi, C., Fan, X. \& Shao, W. (2015). The influence of climate change and anthropogenic activities on annual runoff of Huangfuchuan basin in northwest China. Theoretical and Applied Climatology, 120: 137-146. 